\title{
Bioresorbable Scaffolds: Current Technology and Future Perspectives
}

\author{
Brian Forrestal, M.B.B.S., Brian C. Case, M.D., Charan Yerasi, M.D., Anees \\ Musallam, M.D., Chava Chezar-Azerrad, M.D., and Ron Waksman, M.D.* \\ Section of Interventional Cardiology, MedStar Washington Hospital Center, Washington, DC, USA
}

\begin{abstract}
Metallic drug-eluting stents have led to significant improvements in clinical outcomes but are inherently limited by their caging of the vessel wall. Fully bioresorbable scaffolds (BRS) have emerged in an effort to overcome these limitations, allowing a "leave nothing behind" approach. Although theoretically appealing, the initial experience with BRS technology was limited by increased rates of scaffold thrombosis compared with contemporary stents. This review gives a broad outline of the current BRS technologies and outlines the refinements in BRS design, procedural approach, lesion selection, and post-procedural care that resulted from early BRS trials.
\end{abstract}

KEY WORDS: Bioresorbable scaffold, drug-eluting stent, stent thrombosis, target lesion failure, target lesion revascularization

\footnotetext{
Abbreviations: BRS, bioresorbable scaffolds; CoCr, cobalt chromium; DAPT, dual antiplatelet therapy; DAT, desaminotyrosine polycarbonate; DES, drug-eluting stent; EES, everolimus-eluting stent; MRS, metallic resorbable scaffolds; PDLLA, poly-D, L-lactic acid; PLLA, poly-L-lactic acid; STEMI, ST elevation myocardial infarction; TLF, target lesion failure; TLR, target lesion revascularization.

Citation: Forrestal B, Case BC, Yerasi C, Musallam A, Chezar-Azerrad C, Waksman R. Bioresorbable Scaffolds: Current Technology and Future Perspectives. Rambam Maimonides Med J 2020;11 (2):eoo16. Review. doi:10.5041/RMMJ.10402

Copyright: (C) 2020 Forrestal et al. This is an open-access article. All its content, except where otherwise noted, is distributed under the terms of the Creative Commons Attribution License (http://creativecommons.org/licenses/by/3.0), which permits unrestricted use, distribution, and reproduction in any medium, provided the original work is properly cited.

Conflict of interest: Ron Waksman is on the Advisory Board of Amgen, Boston Scientific, Cardioset, Cardiovascular Systems Inc., Medtronic, Philips, and Pi-Cardia Ltd; is a consultant for Amgen, Biotronik, Boston Scientific, Cardioset, Cardiovascular Systems Inc., Medtronic, Philips, and Pi-Cardia Ltd; has received grant support from AstraZeneca, Biotronik, Boston Scientific, and Chiesi; is on the Speakers Bureau of AstraZeneca and Chiesi; and is an investor in MedAlliance. All other authors reported no potential conflict of interest relevant to this article.

* To whom correspondence should be addressed. E-mail: ron.waksman@medstar.net
} 


\section{INTRODUCTION}

Since their introduction in the mid-1980s, coronary stents have evolved significantly and have led to improvements in the treatment of patients with coronary artery disease. The prevention of acute and subacute vessel closure due to vessel recoil by the initial bare metal stents led to reductions in restenosis rates, a major limitation of balloon angioplasty. ${ }^{1}$ Subsequent generations of stents, with the addition of antiproliferative agents and polymer coatings, led to even further improvements in restenosis rates, and to the widespread adoption of the technology. ${ }^{2}$

As with any new technology, however, there were limitations with leaving a permanent scaffold within the vessel. These included impaired normal vasomotor reactivity 3 and jailing of side branches. Other concerns included initiating the inflammatory host response to the polymer coatings of the device at the vessel wall, leading to neointimal hyperplasia, restenosis, and stent thrombosis. 4 Bioresorbable scaffolds (BRS) were developed to provide all of the short-term benefits of permanent stents but with the added benefit of completely degrading over the medium- to long-term period, allowing full recovery of vasomotor and endothelial function. ${ }^{5,6}$ This strategy of "leave nothing behind" aimed to prevent longterm inflammation, preserve distal bypass grafting sites, and allow unimpeded future vessel imaging.

Although the theoretical benefits of BRS were attractive, the initial generation of BRS devices, principally the Absorb Bioresorbable Vascular Scaffold (Abbott Vascular, Santa Clara, CA, USA), were hampered by increased rates of stent thrombosis compared with contemporary stents. 7,8 This led to the withdrawal of the product from the market in 2017, and a loss of trust in the technology. Newergeneration devices utilizing different bioresorbable materials and featuring improved stent strut thickness may still provide a viable path to the "leave nothing behind" strategy.

Here, we aim to provide an outline of the development of the current BRS technologies and an overview of the field's future directions.

\section{CURRENT DEVICES}

The majority of BRS that have been brought to the clinical trial stage have been based on lactate polymers. Other materials utilized include magnesium alloys, tyrosine copolymers, and iron. Table 1 outlines some of the major BRS that have been brought to clinical trials. The following section outlines some of the key materials used in BRS and design features of the representative devices, with Table 2 outlining their clinical performance. The technologies used for BRS can be broadly categorized as polymeric resorbable scaffolds or metallic resorbable scaffolds (MRS).

\section{Poly-lactate-based BRS}

The majority of the data on BRS has been provided by lactate-based polymer systems, with poly-L-lactic acid (PLLA) the most commonly used polymer. The PLLA polymer is a thermoplastic aliphatic polyester that undergoes hydrolysis upon contact with the blood pool into lactate monomers and, ultimately, water and carbon dioxide when metabolized by the Krebs cycle. ${ }^{9,10}$ For many years PLLA has been used in a variety of other applications, such as resorbable sutures. Compared with metal alloys such as cobalt chromium and stainless steel, which are typically used in modern stents, PLLA has a lower tensile strength and, therefore, requires significantly thicker struts to provide comparable radial strength. ${ }^{11}$ PolyD, L-lactic acid (PDLLA) undergoes a similar breakdown process to PLLA but at a faster rate because of a decreased crystalline structure compared to PLLA.

Several PLLA and PDLLA BRS exist at various stages of development, but the ABSORB clinical program has provided the majority of data on lactatebased BRS.

\section{The Absorb BRS program}

The Absorb BRS was the first BRS approved for use in the United States by the US Food and Drug Administration on the basis of several large, multicenter, randomized controlled trials. The ABSORB II, ABSORB III, ABSORB CHINA, ABSORB JAPAN, TROFI II, and EVERBIO III trials, ${ }^{8,12-16}$ were all largescale, multicenter, prospective trials comparing Absorb to a contemporary cobalt chromium everolimuseluting stent (CoCr-EES) (Abbott Vascular, Santa Clara, CA, USA). Although individual trial-level results demonstrated similar performance characteristics and safety profiles between the two stents, subsequent analyses demonstrated increased rates of scaffold thrombosis at 1 year in the Absorb cohort. ${ }^{17,18}$ This trend appeared to continue to 3 years, ${ }^{19}$ with the additional worrisome finding of increased ischemia-driven target lesion revascularization (TLR) in the Absorb group. 7 Longer-term follow-up to 4 and 5 years post-implantation demonstrated that the risk of adverse events appeared to stabilize after 3 years and was comparable to 
Table 1. Key Design Characteristics of Current Bioresorbable Scaffold Technologies.

\begin{tabular}{|c|c|c|c|c|c|c|}
\hline $\begin{array}{l}\text { Device } \\
\text { (Manufacturer) }\end{array}$ & Drug & $\begin{array}{l}\text { Backbone } \\
\text { Material }\end{array}$ & $\begin{array}{c}\text { Strut } \\
\text { Thickness }(\mu \mathrm{m})\end{array}$ & $\begin{array}{l}\text { Bioresorption } \\
\text { Time (months) }\end{array}$ & $\begin{array}{l}\text { EU CE } \\
\text { Mark }\end{array}$ & $\begin{array}{c}\text { FDA } \\
\text { Approval }\end{array}$ \\
\hline $\begin{array}{l}\text { ABSORB GT1 BRS } \\
\text { (Abbott) }\end{array}$ & Everolimus & PLLA & 156 & $24-36$ & $\underset{2011}{\operatorname{Jan}}$ & July 2016* \\
\hline $\begin{array}{l}\text { DESolve } \\
\text { (Elixir Medical) }\end{array}$ & Novalimus & PLLA & 150 & $24-36$ & $\begin{array}{l}\text { May } \\
2014\end{array}$ & No \\
\hline $\begin{array}{l}\text { ART Pure (Arterial } \\
\text { Remodelling } \\
\text { Technologies) }\end{array}$ & Drug-free & PDLLA & 170 & $12-24$ & $\begin{array}{l}\text { May } \\
2015\end{array}$ & No \\
\hline $\begin{array}{l}\text { MeRes } 100 \text { (Meril } \\
\text { Life Sciences) }\end{array}$ & Sirolimus & PLLA & 180 & 24 & $\begin{array}{l}\text { August } \\
2019\end{array}$ & No \\
\hline $\begin{array}{l}\text { FORTITUDE } \\
\text { (Amaranth } \\
\text { Medical) }\end{array}$ & Sirolimus & PLLA & 150 & $12-24$ & No & No \\
\hline $\begin{array}{l}\text { APTITUDE } \\
\text { (Amaranth } \\
\text { Medical) }\end{array}$ & Sirolimus & PLLA & 115 & $12-24$ & No & No \\
\hline $\begin{array}{l}\text { MAGNITUDE } \\
\text { (Amaranth } \\
\text { Medical) }\end{array}$ & Sirolimus & PLLA & 98 & $12-24$ & No & No \\
\hline $\begin{array}{l}\text { DEFIANCE } \\
\text { (Amaranth } \\
\text { Medical) }\end{array}$ & Sirolimus & PLLA & 85 & $12-24$ & No & No \\
\hline Mirage (Manli) & Sirolimus & PLLA & $125-150$ & 14 & No & No \\
\hline $\begin{array}{l}\text { NeoVas (Lepu } \\
\text { Medical } \\
\text { Technology) }\end{array}$ & Sirolimus & PLLA & 180 & 36 & No & No \\
\hline $\begin{array}{l}\text { Firesorb (Shanghai } \\
\text { MicroPort) }\end{array}$ & Sirolimus & PLLA & $100-125$ & 36 & No & No \\
\hline Falcon (Abbott) & Everolimus & PLLA & $<100$ & & No & No \\
\hline $\begin{array}{l}\text { Fantom (REVA } \\
\text { Medical) }\end{array}$ & Sirolimus & DAT & 125 & 12 & $\begin{array}{l}\text { April } \\
2017\end{array}$ & No \\
\hline $\begin{array}{l}\text { Magmaris } \\
\text { (Biotronik) }\end{array}$ & Sirolimus & Magnesium & $120-150$ & 12 & $\begin{array}{l}\text { June } \\
2016\end{array}$ & No \\
\hline $\begin{array}{l}\text { IBS (Lifetech } \\
\text { Scientific) }\end{array}$ & Sirolimus & Iron & 70 & $>12$ & No & No \\
\hline
\end{tabular}

* US sales discontinued September 2017.

DAT, Desaminotyrosine polycarbonate; PDLLA, poly-D, L-lactic acid; PLLA, poly-L-lactic acid.

Modified with updated data from Jinnouchi $\mathrm{H}$ et al. ${ }^{6}$ with permission, 02018 Springer Nature.

CoCr-EES, ${ }^{12}$ likely reflecting the complete resorption of the scaffold within the vessel wall.

The short- to medium-term concerns raised by the ABSORB program led to the withdrawal from the US market in 2018.4 However, the program provided some valuable lessons, in particular in BRS deployment techniques. Optimal deployment techniques that aimed at reducing inadequate vessel sizing, malposition, and scaffold underexpansion appeared, in smaller sub-studies, to reduce the rates of scaffold thrombosis, and the "PSP" technique (predilation, proper sizing, and post-dilation) emerged. These findings were not consistent across all studies 
Table 2. Key Clinical Performance Measures of Selected Bioresorbable Scaffolds.

\begin{tabular}{|c|c|c|c|c|c|c|c|}
\hline $\begin{array}{l}\text { Device } \\
\text { (Manufacturer) }\end{array}$ & $\begin{array}{l}\text { Patients } \\
\text { Enrolled }\end{array}$ & $\begin{array}{l}\text { Angiographic } \\
\text { Follow-up } \\
\text { (months post } \\
\text { implant) }\end{array}$ & $\begin{array}{c}\text { Late } \\
\text { Lumen } \\
\text { Loss }(\mathrm{mm})\end{array}$ & $\begin{array}{l}\text { Clinical Follow- } \\
\text { up Period } \\
\text { (months) }\end{array}$ & $\begin{array}{l}\text { TLF } \\
(\%)\end{array}$ & $\begin{array}{c}\text { Scaffold } \\
\text { Thrombosis } \\
(\%)\end{array}$ & $\begin{array}{l}\text { Ischemia- } \\
\text { driven TLR } \\
\text { (\%) }\end{array}$ \\
\hline $\begin{array}{l}\text { ABSORB GT1 } \\
\text { BRS (Abbott) }\end{array}$ & $2161^{*}$ & 6 & $0.19 \pm 0.18$ & 60 & 11.6 & 2.5 & 8.4 \\
\hline $\begin{array}{l}\text { DESolve Nx } \\
\text { (Elixir Medical) }\end{array}$ & 122 & 6 & $0.20 \pm 0.32$ & 60 & 7.4 & 0 & 4.1 \\
\hline $\begin{array}{l}\text { ART Pure } \\
\text { (Arterial } \\
\text { Remodelling } \\
\text { Technologies) }\end{array}$ & 30 & 6 & - & - & - & - & - \\
\hline $\begin{array}{l}\text { MeRes } 100 \\
\text { (Meril Life } \\
\text { Sciences) }\end{array}$ & 108 & 6 & $0.15 \pm 0.23$ & 12 & - & 0 & 0.9 \\
\hline $\begin{array}{l}\text { FORTITUDE } \\
\text { (Amaranth } \\
\text { Medical) }\end{array}$ & 63 & 24 & $0.27 \pm 0.37$ & 24 & 4.9 & 1.8 & 5.3 \\
\hline $\begin{array}{l}\text { APTITUDE } \\
\text { (Amaranth } \\
\text { Medical) }\end{array}$ & 60 & 9 & $0.33 \pm 0.36$ & 24 & 3.4 & 0 & 0 \\
\hline $\begin{array}{l}\text { MAGNITUDE } \\
\text { (Amaranth } \\
\text { Medical) }\end{array}$ & 70 & 9 & $0.19 \pm 0.16$ & 9 & 2.9 & 0 & 0 \\
\hline Mirage (Manli) & 35 & 12 & $0.37 \pm 0.14$ & 12 & 17.2 & 3.4 & 17.2 \\
\hline $\begin{array}{l}\text { NeoVas (Lepu } \\
\text { Medical } \\
\text { Technology) }\end{array}$ & 1103 & MSCT follow-up & - & 12 & 3.0 & 0.5 & 1.7 \\
\hline $\begin{array}{l}\text { Fantom (REVA } \\
\text { Medical) }\end{array}$ & 117 & 6 & $0.25 \pm 0.40$ & 24 & 4.2 & 0.8 & 2.9 \\
\hline $\begin{array}{l}\text { Magmaris } \\
\text { (Biotronik) }\end{array}$ & 1075 & 12 & $0.52 \pm 0.39$ & 36 & 4.3 & 0.5 & 2.4 \\
\hline
\end{tabular}

* Pooled analysis of ABSORB II, ABSORB JAPAN, ABSORB CHINA, ABSORB III; >150,000 commercially treated patients worldwide.

MSCT, multi-slice computed tomography; TLF, target lesion failure; TLR, target lesion revascularization.

Modified with updated data from Jinnouchi $\mathrm{H}$ et al. ${ }^{6}$ with permission, (C2018 Springer Nature.

examining the effect of pre-dilation and post-dilation, and it remains unclear whether the risk of scaffold thrombosis related to the Absorb device or the deployment technique. ${ }^{20}$

\section{Desaminotyrosine Polycarbonate-based BRS}

Desaminotyrosine polycarbonate (DAT) is a polycarbonate copolymer of tyrosine analogues and is combined with biocompatible hydroxyesters when used in BRS. The DAT polymer has similar radial strength and recoil characteristics to metallic stents ${ }^{21}$ and has the added benefit of allowing combination with low levels (3\%) of iodine to allow improved visualization under fluoroscopy. 6,21

\section{The FANTOM program}

The Fantom stent (REVA Medical, San Diego, CA, USA), based on DAT, has a $125-\mu \mathrm{m}$ strut and incorporates iodine into the scaffold to improve visualization. Upon breakdown, the stent elutes sirolimus, with $80 \%$ of strut degradation occurring in the first 
12 months and complete resorption occurring at 36 months. ${ }^{21}$ Additionally, the strut design and DAT allow for single inflation.

The FANTOM II study enrolled 240 patients across 28 sites and demonstrated promising safety and efficacy at 12 months, with target lesion failure (TLF) occurring in $4.2 \%$ of patients, with only 1 event of scaffold thrombosis. ${ }^{21}$ Despite these initial successes, the company has been beset by financial difficulties. In early 2019 it voluntarily suspended trading, ${ }^{22}$ and filed for bankruptcy protection in early $2020 .{ }^{23}$

\section{Magnesium-based BRS}

Magnesium in its pure elemental form does not have the radial strength required to prevent acute elastic recoil. 6 When combined with zinc and manganese, however, the mechanical properties are comparable to stainless steel stents, with low elastic recoil (less than 8\%), minimal shortening after inflation (less than $5 \%$ ), and high collapse pressures (o.8 to 1.5 bar). ${ }^{24}$

Once deployed and in the body, the magnesium gradually breaks down into inorganic ions and is replaced by amorphous hydroxyapatite, a calciumphosphorus compound. Additional processes, such as electropolishing of the alloy, can slow the degradation process, with complete degradation occurring by 12 months. 25 Anti-neoproliferative agents are incorporated into an outer layer of PLLA to allow controlled drug elution. Interestingly, ex vivo models have demonstrated that the ionic properties of magnesium may have intrinsic antithrombotic effects, driven by decreased inflammatory cell and platelet deposition. ${ }^{26}$

\section{The Magmaris program}

The Magmaris program began with the AMS 1 stent (Biotronik AG, Bülach, Switzerland), which was bulky, hard to deliver, and limited by significant vessel recoil due to poor radial strength. This led to unacceptably high rates of TLR (45\%) and major adverse cardiovascular events (26.7\%) as demonstrated in the PROGRESS-AMS study. ${ }^{24}$ The AMS 2 and AMS 3 stents incorporated changes in the strut design, the magnesium alloy, and the outer polymer matrix, aimed at improving neointimal hyperplasia and vessel recoil. The best-performing of these early BRS-namely the AMS 3-was renamed DrugEluting AMS 1.o (DREAMS), ${ }^{27}$ leading to the firstin-man BIOSOLVE-I ${ }^{28}$ clinical trial.
The BIOSOLVE-I trial demonstrated substantial improvements compared to the PROGRESS-AMS study, with TLR rates of $4.7 \%$ and TLF rates of $7 \%$ at 12 months, but still underperformed in comparison with contemporary stents. ${ }^{29}$ With further improvements in design-such as the incorporation of tantalum markers to enhance visualization, switching from a poly-D-lactc acid (PDLA) to a PLLA outer coating, and improved deployment technique-the DREAMS 2G scaffold was tested in the BIOSOLVEII and BIOSOLVE-III trials. ${ }^{30}$ Both trials enrolled stable patients with simple de novo lesions. A recently presented pooled analysis of BIOSOLVE-II and BIOSOLVE-III demonstrated similar rates of TLF $(6.4 \%, n=174)$ and clinically driven revascularization $(3.7 \%, n=174)$ at 36 months' follow-up when compared to second-generation drug-eluting stents (DES). No stent thrombosis events were reported. ${ }^{31}$ The ongoing BIOSOLVE-IV all-comers registry, with more than 1,000 patients enrolled, shows similar TLF rates to those of the earlier, smaller-scale BIOSOLVE-II and BIOSOLVE-III trials. ${ }^{2}$

Despite the DREAMS 2G (marketed as Magmaris) scaffold gaining CE mark approval in 2016, the lessons from the failure of the ABSORB program were at the forefront of operator's experiences with BRS technology. Urging caution, a consensus paper by experts in the field recommended restricting the use of Magmaris in certain areas until further data became available, specifically recommending against the use of Magmaris in situations such as ST elevation myocardial infarction (STEMI), calcified lesions, poor medication compliance, or ostial lesions, restricting its use to stable patients with simple de novo lesions. 33

The third generation of Magmaris, $3 \mathrm{G}$, is ready to start clinical trials. This $3 \mathrm{G}$ platform utilizes Biomag as scaffold material, has thinner struts, markers enhancing visualization, and a large matrix of sizes and lengths to allow proper device selection.

\section{Iron-based BRS}

Iron-based devices offer the advantage of being highly biocompatible with high radial strength but have been limited by a long corrosion period and clearance from the vessel. 34 Previous in vitro studies have shown that a 26-mm long, pure iron-based stent releases $41 \mathrm{mg} / \mathrm{month}$ of iron into the bloodstream, equivalent to the typical oral intake of dietary iron over the same period. 35 Animal models up to 18 months have not shown evidence of iron toxicity. ${ }^{36}$ Pre-clinical porcine models have shown that the iron 
bioresorbable coronary scaffold (IBS) from Lifetech Scientific (Shenzhen, Guangdong, China) displays similar efficacy and safety profiles to currentgeneration everolimus DES, 37 but no current data in humans are available.

\section{FUTURE DIRECTIONS OF BRS TECHNOLOGY}

\section{Scaffold Design}

Strut thickness is one of the principal features thought to be a mechanism behind the rates of stent thrombosis seen with early-generation BRS. $3^{8}$ Thicker struts (greater than $150 \mu \mathrm{m}$ ) were required to provide enough radial strength to prevent vessel recoil but led to longer resorption times. Additional concerns, such as polymer dismantling and scaffold discontinuity, have also been shown to be factors related to thicker strut designs leading to adverse events. 39

Future generations of BRS are in development, and, through innovations in stent design, reductions in strut thickness have been achieved (MeRes1oo, Meril Life Science, Gujaret, India; Mirage, Manli Cardiology, Singapore; MAGNITUDE, Amaranth Medical, Mountain View, CA, USA; Firesorb, MicroPort, Shanghai, China). In addition to allowing smaller crossing profiles, which improves deliverability, thinner struts have been shown to reduce the shear stress at the vessel wall, allowing for less turbulent blood flow, improved endothelization, and reduced thrombus formation. ${ }^{40}$ Thinner struts have also been shown to reduce restenosis and periprocedural myocardial infarction rates. 41,42 Through these innovations in stent and strut design, lower-profile scaffolds have been made possible without sacrificing radial strength. Trials are ongoing to evaluate whether these innovations will lead to improved outcomes compared to early-generation devices.

\section{Procedural Considerations}

Despite improvements in scaffold design, the importance of correct deployment technique cannot be underestimated. Underexpansion and malapposition were the two most common procedural-related factors leading to adverse outcomes in early clinical trials. 43 With the implementation of the PSP technique steps to mitigate underexpansion and malapposition, the incidence of stent thrombosis was significantly reduced and was comparable with everolimus DES.44,45 The 4P technique (patient selection, proper sizing, pre-dilation, and post-dilation) is similar and is aimed at preventing underexpansion and malapposition when using MRS. Future trials utilizing BRS should only proceed with such mandatory procedural steps to mitigate these risks and ensure a favorable result.

\section{Patient and Lesion Selection}

The ABSORB and Magmaris clinical programs have also provided several important lessons on patient and lesion selection. Specific anatomic characteristics seem more amenable to BRS with the current generation of scaffolds.

Vessel size is a key factor, with small vessels $(<2.25 \mathrm{~mm})$ displaying higher rates of scaffold thrombosis and stent thrombosis, 45 and large vessels $(>3.75 \mathrm{~mm})$ risking underexpansion or scaffold fracture. ${ }^{6}$ Other complex anatomical subsets such as ostial lesions, 46 bifurcation, severely calcified lesions, ${ }^{47}$ and in-stent restenosis ${ }^{8}$ have all shown inferior outcomes in small-scale substudies and clinical trials.

Patient-related factors and the clinical presentations of patients also play a role. When used in STEMI, both magnesium- and lactate-based scaffolds have demonstrated inferior event rates compared with everolimus DES.49,50 When used in nonSTEMI patients, the Magmaris BRS appears safe when compared to EES at 12 months, but long-term data are not yet available. ${ }^{11}$

Future clinical trials should aim to adequately assess the safety and efficacy of BRS in higher-risk anatomic and patient subsets. With improvements in scaffold design, preservation of vessel lumen and vasomotion may become possible in situations such as in-stent restenosis and chronic total occlusions.

\section{Dual Antiplatelet Therapy after BRS}

Understanding the BRS resorption period is an important factor when considering dual antiplatelet therapy (DAPT) duration. During resorption, scaffold discontinuity and polymer breakdown may provide a nidus of thrombus formation, so DAPT should be maintained until complete scaffold resorption is achieved. As with all DAPT, however, this needs to be balanced against the increased risk of bleeding events. As scaffold technology advances and quicker resorption times are achieved, thus reducing DAPT duration, BRS may become more suitable in patients at high risk of bleeding, but trials will be needed. Current European guidelines treat polymeric and metallic resorbable scaffolds as a 
single class and recommend a minimum of 12 months of DAPT (class IIA C). $5^{2}$

\section{Future Directions}

With the latest improvements of the permanent metallic scaffolds, and their performance with short DAPT without stent thrombosis, the question arises as to what the role of bioresorbable scaffolds should be in 2020 and beyond. Recent data suggest an ongoing TLR rate of $2 \%$ per year with secondgeneration DES.53 The BRS technology may provide a way to avoid these late events, but the technology needs to at least perform as well as permanent metallic stents in the short term and better in the long term. This was not achieved with the first generation of BRS technology, and continued iterations of the technology are warranted to meet this goal.

\section{CONCLUSIONS}

The BRS technology still holds promise. The lessons learned from the ABSORB program about patient and lesion selection, deployment technique, and the need for long-term follow-up were all valuable. The key to ensuring that the clinical community does not lose faith and prematurely turn its back on future $\mathrm{BRS}$ technologies lies in rigorous, adequately powered clinical trials with long-term ( $>5$ years) followup. Ongoing device development focusing on new materials and thinner struts may still allow a path to the "leave nothing behind" strategy.

\section{REFERENCES}

1. Serruys PW, de Jaegere P, Kiemeneij F, et al. A comparison of balloon-expandable-stent implantation with balloon angioplasty in patients with coronary artery disease. Benestent Study Group. N Engl J Med 1994; 331:489-95. CrossRef

2. Stefanini GG, Holmes DR Jr. Drug-eluting coronaryartery stents. N Engl J Med 2013;368:254-65. CrossRef

3. Joner M, Finn AV, Farb A, et al. Pathology of drugeluting stents in humans: delayed healing and late thrombotic risk. J Am Coll Cardiol 2006;48:193-202. CrossRef

4. Forrestal B, Lipinski MJ. Bioresorbable scaffolds: fading away or hope for the future? The American College of Cardiology; 2018; February 07 [Expert analysis]. Available at: https://www.acc.org/latestin-cardiology/articles/2018/02/07/07/45/ bioresorbable-scaffolds (accessed April 21, 2020).
5. Serruys PW, Garcia-Garcia HM, Onuma Y. From metallic cages to transient bioresorbable scaffolds: change in paradigm of coronary revascularization in the upcoming decade? Eur Heart J 2012;33:16-25b. CrossRef

6. Jinnouchi H, Torii S, Sakamoto A, Kolodgie FD, Virmani R, Finn AV. Fully bioresorbable vascular scaffolds: lessons learned and future directions. Nat Rev Cardiol 2019;16:286-304. CrossRef

7. Wykrzykowska JJ, Kraak RP, Hofma SH, et al. Bioresorbable scaffolds versus metallic stents in routine PCI. N Engl J Med 2017;376:2319-28 CrossRef

8. Serruys PW, Chevalier B, Sotomi Y, et al. Comparison of an everolimus-eluting bioresorbable scaffold with an everolimus-eluting metallic stent for the treatment of coronary artery stenosis (ABSORB II): a 3 year, randomised, controlled, single-blind, multicentre clinical trial. Lancet 2016;388:2479-91. CrossRef

9. Lipinski MJ, Escarcega RO, Lhermusier T, Waksman $R$. The effects of novel, bioresorbable scaffolds on coronary vascular pathophysiology. J Cardiovasc Transl Res 2014;7:413-25. CrossRef

10. Serruys PW, Ormiston JA, Onuma Y, et al. A bioabsorbable everolimus-eluting coronary stent system (ABSORB): 2-year outcomes and results from multiple imaging methods. Lancet 2009;373:897-910. CrossRef

11. Onuma Y, Serruys PW. Bioresorbable scaffold: the advent of a new era in percutaneous coronary and peripheral revascularization? Circulation 2011;123: 779-97. CrossRef

12. Kereiakes DJ, Ellis SG, Metzger DC, et al. Clinical outcomes before and after complete everolimuseluting bioresorbable scaffold resorption: five-year follow-up from the ABSORB III trial. Circulation 2019;140:1895-903. CrossRef

13. Xu B, Yang Y, Han Y, et al. Comparison of everolimuseluting bioresorbable vascular scaffolds and metallic stents: three-year clinical outcomes from the ABSORB China randomised trial. EuroIntervention 2018;14: e554-61. $\underline{\text { CrossRef }}$

14. Okada K, Honda Y, Kitahara H, et al. Bioresorbable scaffold for treatment of coronary artery lesions: intravascular ultrasound results from the ABSORB Japan trial. JACC Cardiovasc Interv 2018;11:648-61. CrossRef

15. Katagiri Y, Onuma Y, Asano T, et al. Three-year follow-up of the randomised comparison between an everolimus-eluting bioresorbable scaffold and a durable polymer everolimus-eluting metallic stent in patients with ST-segment elevation myocardial infarction (TROFI II trial). EuroIntervention 2018;14: e1224-6. CrossRef 
16. Arroyo D, Gendre G, Schukraft S, et al. Comparison of everolimus- and biolimus-eluting coronary stents with everolimus-eluting bioresorbable vascular scaffolds: two-year clinical outcomes of the EVERBIO II trial. Int J Cardiol 2017;243:121-5. $\underline{\text { CrossRef }}$

17. Lipinski MJ, Escarcega RO, Baker NC, et al. Scaffold thrombosis after percutaneous coronary intervention with ABSORB bioresorbable vascular scaffold: a systematic review and meta-analysis. JACC Cardiovasc Interv 2016;9:12-24. CrossRef

18. Stone GW, Gao R, Kimura T, et al. 1-Year outcomes with the Absorb bioresorbable scaffold in patients with coronary artery disease: a patient-level, pooled meta-analysis. Lancet 2016;387:1277-89. CrossRef

19. Costa JR Jr, Abizaid A, Whitbourn R, et al. Threeyear clinical outcomes of patients treated with everolimus-eluting bioresorbable vascular scaffolds: final results of the ABSORB EXTEND trial. Catheter Cardiovasc Interv 2019;93:E1-7. CrossRef

20. Colombo A, Ruparelia N. Who is thrombogenic: the scaffold or the doctor? Back to the future! JACC Cardiovasc Interv 2016;9:25-7. CrossRef

21. Abizaid A, Carrie D, Frey N, et al. 6-Month clinical and angiographic outcomes of a novel radiopaque sirolimus-eluting bioresorbable vascular scaffold: the FANTOM II study. JACC Cardiovasc Interv 2017;10: 1832-8. $\underline{\text { CrossRef }}$

22. Dropwiewski K. REVA announces extension to voluntary suspension of trading. CardioVascular News 2019; February 26. Available at: http://cardiac vascularnews.com/reva-announces-extension-tovoluntary-suspension-of-trading/ (accessed April 21, 2020).

23. Whooley S. Reva Medical files for bankruptcy. Mass Device 2020; January 15. Available at: https://www. massdevice.com/reva-medical-files-for-bankruptcy/ (accessed April 21, 2020).

24. Erbel R, Di Mario C, Bartunek J, et al. Temporary scaffolding of coronary arteries with bioabsorbable magnesium stents: a prospective, non-randomised multicentre trial. Lancet 2007;369:1869-75. $\underline{\text { CrossRef }}$

25. Campos CM, Muramatsu T, Iqbal J, et al. Bioresorbable drug-eluting magnesium-alloy scaffold for treatment of coronary artery disease. Int J Mol Sci 2013; 14:24492-500. $\underline{\text { CrossRef }}$

26. Waksman R, Lipinski MJ, Acampado E, et al. Comparison of acute thrombogenicity for metallic and polymeric bioabsorbable scaffolds: Magmaris versus Absorb in a porcine arteriovenous shunt model. Circ Cardiovasc Interv 2017;10:e004762. CrossRef

27. Rapetto C, Leoncini M. Magmaris: a new generation metallic sirolimus-eluting fully bioresorbable scaf- fold: present status and future perspectives. J Thorac Dis 2017;9:S903-1 CrossRef

28. Haude M, Erbel R, Erne P, et al. Safety and performance of the drug-eluting absorbable metal scaffold (DREAMS) in patients with de-novo coronary lesions: 12 month results of the prospective, multicentre, first-in-man BIOSOLVE-I trial. Lancet 2013; 381:836-44. $\underline{\text { CrossRef }}$

29. Haude M, Erbel R, Erne P, et al. Safety and performance of the DRug-Eluting Absorbable Metal Scaffold (DREAMS) in patients with de novo coronary lesions: 3 -year results of the prospective, multicentre, first-inman BIOSOLVE-I trial. EuroIntervention 2016;12: e160-6. CrossRef

30. Haude $\mathrm{M}$, Ince $\mathrm{H}$, Kische $\mathrm{S}$, et al. Safety and clinical performance of a drug eluting absorbable metal scaffold in the treatment of subjects with de novo lesions in native coronary arteries: pooled 12-month outcomes of BIOSOLVE-II and BIOSOLVE-III. Catheter Cardiovasc Interv 2018;92:E502-11. $\underline{\text { CrossRef }}$

31. Haude $\mathrm{M}$, Ince $\mathrm{H}$, Kische $\mathrm{S}$, et al. TCT-188 safety and clinical performance of the drug-eluting absorbable metal scaffold in the treatment of subjects with de novo lesions in native coronary arteries at 36-month follow-up: BIOSOLVE-II and BIOSOLVE-III. J Am Coll Cardiol 2019;74:B187. CrossRef

32. Verheye S, Wlodarczak A, Montorsi P, et al. TCT-45 safety and performance of the resorbable magnesium scaffold, Magmaris, in a real-world setting: first cohort subjects at 12-month follow-up of the BIOSOLVEIV registry. J Am Coll Cardiol 2019;74(13 Suppl):B45. CrossRef

33. Fajadet J, Haude M, Joner M, et al. Magmaris preliminary recommendation upon commercial launch: a consensus from the expert panel on 14 April 2016. EuroIntervention 2016;12:828-33. CrossRef

34. Waksman R, Pakala R, Baffour R, Seabron R, Hellinga D, Tio FO. Short-term effects of biocorrodible iron stents in porcine coronary arteries. $\mathrm{J}$ Interv Cardiol 2008;21:15-20. CrossRef

35. Hideo-Kajita A, Wopperer S, Bocchino Seleme V, Harada Ribeiro M, Campos CM. The development of magnesium-based resorbable and iron-based biocorrodible metal scaffold technology and biomedical applications in coronary artery disease patients. Appl Sci 2019;9:3527. $\underline{\text { CrossRef }}$

36. Peuster M, Wohlsein P, Brugmann M, et al. A novel approach to temporary stenting: degradable cardiovascular stents produced from corrodible metal-results 6-18 months after implantation into New Zealand white rabbits. Heart 2001;86:563-9. $\underline{\text { CrossRef }}$

37. Zheng JF, Qiu H, Tian Y, et al. Preclinical evaluation of a novel sirolimus-eluting iron bioresorbable coro- 
nary scaffold in porcine coronary artery at 6 months. JACC Cardiovasc Interv 2019;12:245-55. CrossRef

38. Sakamoto A, Jinnouchi H, Torii S, Virmani R, Finn AV. Understanding the impact of stent and scaffold material and strut design on coronary artery thrombosis from the basic and clinical points of view. Bioengineering (Basel) 2018;5:71. $\underline{\text { CrossRef }}$

39. Yahagi K, Yang Y, Torii S, et al. Comparison of a drug-free early programmed dismantling PDLLA bioresorbable scaffold and a metallic stent in a porcine coronary artery model at 3-year follow-up. J Am Heart Assoc 2017;6:e005693. CrossRef

40. Gijsen F, Katagiri Y, Barlis P, et al. Expert recommendations on the assessment of wall shear stress in human coronary arteries: existing methodologies, technical considerations, and clinical applications. Eur Heart J 2019;40:3421-33.

41. Bangalore S, Toklu B, Patel N, Feit F, Stone GW. Newer-generation ultrathin strut drug-eluting stents versus older second-generation thicker strut drugeluting stents for coronary artery disease. Circulation 2018;138:2216-26. CrossRef

42. Iantorno M, Lipinski MJ, Garcia-Garcia HM, et al. Meta-analysis of the impact of strut thickness on outcomes in patients with drug-eluting stents in a coronary artery. Am J Cardiol 2018;122:1652-60. $\underline{\text { CrossRef }}$

43. Bangalore S, Bezerra HG, Rizik DG, et al. The state of the absorb bioresorbable scaffold: consensus from an expert panel. JACC Cardiovasc Interv 2017;10:234959. $\underline{\text { CrossRef }}$

44. Puricel S, Cuculi F, Weissner M, et al. Bioresorbable coronary scaffold thrombosis: multicenter comprehensive analysis of clinical presentation, mechanisms, and predictors. J Am Coll Cardiol 2016;67:92131. CrossRef

45. Ellis SG, Gori T, Serruys PW, et al. Clinical, angiographic, and procedural correlates of very late absorb scaffold thrombosis: multistudy registry results. JACC Cardiovasc Interv 2018;11:638-44. CrossRef

46. Gori T, Wiebe J, Capodanno D, et al. Early and midterm outcomes of bioresorbable vascular scaffolds for ostial coronary lesions: insights from the GHOSTEU registry. EuroIntervention 2016;12:e550-6. CrossRef

47. Gori T, Guagliumi G, Munzel T. Absorb bioresorbable scaffold implantation for the treatment of an ostial chronic total occlusion. Int J Cardiol 2014;172:e3778. CrossRef

48. Moscarella E, Ielasi A, Granata F, et al. Long-term clinical outcomes after bioresorbable vascular scaffold implantation for the treatment of coronary instent restenosis: a multicenter Italian experience. Circ Cardiovasc Interv 2016;9:eoo3148. $\underline{\text { CrossRef }}$

49. Sabate M, Alfonso F, Cequier A, et al. Magnesiumbased resorbable scaffold versus permanent metallic sirolimus-eluting stent in patients with ST-segment elevation myocardial infarction: the MAGSTEMI randomized clinical trial. Circulation 2019;140:190416. $\underline{\text { CrossRef }}$

50. Brugaletta S, Gori T, Tousek $\mathrm{P}$, et al. Very long-term outcome of ABSORB bioresorbable vascular scaffold vs. everolimus-eluting metallic stent in ST-segment elevation myocardial infarction: 5-year results of the BVS-EXAMINATION study. EuroIntervention 2020; 15:1436-43. CrossRef

51. Wlodarczak A, Lanocha M, Jastrzebski A, et al. Early outcome of magnesium bioresorbable scaffold implantation in acute coronary syndrome-the initial report from the Magmaris-ACS registry. Catheter Cardiovasc Interv 2019;93:E287-92. $\underline{\text { CrossRef }}$

52. Valgimigli M, Bueno H, Byrne RA, et al. 2017 ESC focused update on dual antiplatelet therapy in coronary artery disease developed in collaboration with EACTS: The Task Force for dual antiplatelet therapy in coronary artery disease of the European Society of Cardiology (ESC) and of the European Association for Cardio-Thoracic Surgery (EACTS). Eur Heart J 2018; 39:213-6o. CrossRef

53. Madhavan MV, Kirtane AJ, Redfors B, et al. Stentrelated adverse events $>1$ year after percutaneous coronary intervention. J Am Coll Cardiol 2020;75: 590-604. $\underline{\text { CrossRef }}$ 